\title{
MICROLOBIUSXYLON PARANAENSIS GEN. ET SP. NOV. (FABACEAE, MIMOSOIDEAE) FROM THE PLIOCENE-PLEISTOCENE OF ITUZAINGÓ FORMATION, PARANÁ BASIN, ARGENTINA
}

\author{
MARÍA JIMENA FRANCO \& MARIANA BREA \\ Laboratorio de Paleobotánica, Centro de Investigaciones Científicas (CICYTTP-Diamante, CONICET), Materi y España SN, \\ E3105BWA Diamante, Entre Ríos, Argentina.jimenafr@gmail.com, cidmbrea@infoaire.com.ar
}

\begin{abstract}
A fossil wood with Fabaceae affinity from the Pliocene-Pleistocene sediments of Ituzaingó Formation is described. The silicified wood was collected at the Toma Vieja fossil locality, Paraná Basin, Argentina. The relationship and comparison with the nearest living relatives (NLRs) are discussed. Wood anatomical characters suggest an affinity with the genus Microlobius C. Presl. In South America, the genus Microlobius occurs in Brazil, Bolivia (Santa Cruz), Argentina (Chaco and Formosa) and Paraguay and is an important extant element of the Paraguay-Paraná system. The presence of this fossil in the Ituzaingó Formation supports the idea that the morphogenus Microlobiusxylon might have been an important component of seasonally dry tropical forests (SDTFs) during the Pliocene-Pleistocene. Today, this forest type has a relict distribution, occurring in isolated localities in the north of Argentina, southeast of Bolivia and Brazil, but in the past were more widespread to the east and south in South America. The presence of Microlobiusxylon paranaensis gen. et sp. nov. would indicate a temperate-warm climate during the Pliocene-Pleistocene.
\end{abstract}

Key words: fossil wood, Fabaceae, Mimosoideae, Microlobiusxylon, Ituzaingó Formation, Argentina.

RESUMO - É descrita uma madeira fóssil afim à família Fabaceae em sedimentitos plio-pleistocênicos da Formação Ituzaingó. A madeira silicificada foi coletada na localidade fossilífera Toma Vieja (Paraná, Argentina). O lenho fóssil foi comparado com seu parente atual mais próximo. Sua estrutura anatômica sugere afinidade com o gênero Microlobius C. Presl. Na América do Sul, o gênero Microlobius aparece no Brasil, Bolívia (Santa Cruz), Argentina (Chaco e Formosa) e Paraguai, e é um gênero importante do sistema Paraguai-Paraná. A presença deste fóssil na Formação Ituzaingó avaliza a ideia de que o morfogênero Microlobiusxylon foi um membro importante das florestas tropicais sazonais (SDTFs) durante o Plio-Pleistoceno. Estas florestas são relictos em localidades isoladas no norte da Argentina e no sudeste da Bolívia e do Brasil, mas no passado estendeu-se mais para o leste e o sul da América do Sul. Microlobiusxylon paranaensis gen. et sp. nov. sugere a vigência de um clima temperado-cálido ao longo do Plio-Pleistoceno.

Palavras-chave: madeira fóssil, Fabaceae, Mimosoideae, Microlobiusxylon, Formação Ituzaingó, Argentina.

\section{INTRODUCTION}

The Ituzaingó Formation was first defined by De Alba (1953) and formalized by Herbst (1971) and Herbst et al. (1976). This formation has been interpreted as consisting of fluvial deposits (Herbst, 1971, 2000; Iriondo \& Rodríguez, 1973; Herbst et al., 1976; Iriondo, 1979, 1980; Herbst \& Santa Cruz, 1985; Jalfin, 1988; Anis et al., 2005; Iriondo \& Kröhling, 2009). In 1846, D'Orbigny recognized these deposits as "Tertiare Guaranien" or "grès ferrugineux". The Ituzaingó Formation is widely distributed in the western riverside cliff of the Paraná River, from north of Corrientes province to the south near Paraná city, in Entre Ríos province (Herbst, 2000; Anis et al., 2005). In the Argentinian subsurface, it extends from the west of Corrientes and Entre Ríos to the latitude of Paraná city, to the east of Chaco and most of Santa Fe, east of Córdoba, and northern Buenos Aires province (Herbst, 2000). The sand of the Ituzaingó Formation is recycled from Mesozoic Gondwanan eolian deposits. This fluvial unit was deposited by the divagation of the Paleoparaná river course under warm and humid climatic conditions (Iriondo, 1996).

The Ituzaingó Formation contains palynomorphs, leaf compressions and cuticles (Anzótegui, 1975, 1980; Lutz, 1993; Anzótegui \& Lutz, 1987; Caccavari \& Anzótegui, 1987; Garralla, 1987; Anzótegui \& Acevedo, 1995; Anzótegui \& Garralla, 2004; Zucol et al., 2004; Lutz et al., 2007). There are a few reports of fossil wood and culms in the Ituzaingó Formation, including remains assigned to the Anacardiaceae, Fabaceae (Mimosoideae), Moraceae, Rutaceae and Bambusoideae families (Lutz, 1979, 1991; Brea \& Zucol, 2007; Franco, 2008a,b, 2009; Franco \& Brea, 2009).

The purpose of this paper is to describe a fossil wood that has characteristics of the Mimosoideae (Fabaceae), which is a pantropical subfamily of the Fabaceae, comprising 78 genera and 3,270 species (Lewis et al., 2005). The Mimosoideae are mostly tropical to subtropical in distribution, and are major components of arid and semiarid regions throughout the world (Luckow et al., 2003). The ecological and distribution 
characteristics of the nearest living relatives (NLRs) of this wood are used to make paleogeographic and paleoecological inferences. This fossil wood was compared with extant species from the region, especially in present-day Argentinean woods, and this silicified wood is most similar to Microlobius C. Presl.

\section{MATERIAL AND METHODS}

The specimen was collected in Toma Vieja fossil locality, situated on the left margin of the Paraná River, near Paraná city, Argentina (31 42 '13.7'S, 60²8'41.9'W; Figure 1). In Toma Vieja locality, the Ituzaingó Formation (PliocenePleistocene) is $14 \mathrm{~m}$ thick, and the fossiliferous level has well-preserved fossil woods. This unit is composed of sands and consolidated and unconsolidated sandstones, almost exclusively of quartz, with a granulometry that ranges from fine to coarse sands, occasionally whitish, yellowish conglomerates and, occasionally, reddish-brown and dark brownish conglomerates. Dark grey and greenish silty lens intercalations are common among the sands (Iriondo \& Rodríguez, 1973; Aceñolaza \& Sayago, 1980; Herbst \& Santa Cruz, 1985; Iriondo et al., 1998; Herbst, 2000). Tangential cross-bedding, troughs and planar bedding are common (Figure 2). Puerto Alvear Formation (Lower Pleistocene) overlies unconformably the Ituzaingó Formation and underlies unconformably the Hernandarias Formation (Middle Pleistocene), which underlies the Tezanos Pinto Formation (Upper Pleistocene-Holocene) (Figure 2).

The wood is silicified. It was thin-sectioned using techniques employed for rock specimens. The quantitative values provided in the anatomical description are averages of at least 25 measurements. The average is cited first, followed by minimum and maximum values (in parentheses). The IAWA recommendations for hardwood identification terminology (IAWA Committee, 1989) were followed and the Carlquist Comparative Wood Anatomy
(2001) was used to describe the wood anatomy. Also, Gregory's list (1994) was used for the search of the indispensable bibliography. Systematics follows the APGII (2003) classification.

The identification of the fossil wood samples was done using wood atlases and descriptions of Wagemann (1948), Metcalfe \& Chalk (1950), Tortorelli (1956), Barros \& Callado (1997), Richter \& Dallwitz (2000), InsideWood database (2004onwards) and Wheeler et al. (2004, 2007). The diagnostic anatomical characters of Fabaceae were taken from Metcalfe \& Chalk (1950), Tortorelli (1956), Dimitri(1978), Baretta-Kuipers (1981), Gros (1992), Wheeler \& Baas (1992), Richter \& Dallwitz (2000), InsideWood database (2004-onwards) and Evans et al. (2006).

The specimen was studied with a Nikon Eclipse E200 microscope (using 40x, 100x, 400x and 1,000x magnification levels), and the microphotographs were taken with a Nikon Coolpix 990 digital camera.

The fossil wood and microscope slides are deposited in the Laboratorio de Paleobotánica, CICYTTP-CONICET, Diamante, Argentina, under the acronyms CIDPALBO 25, CIDPALBOmic 675 .

\section{SYSTEMATIC PALEONTOLOGY}

Order FABALES Bromhead, 1838

Family FABACEAE Lindley, 1836

Subfamily MIMOSOIDEAE Lindley, 1836

Genus Microlobiusxylon gen. nov.

\section{Microlobiusxylon paranaensis sp. nov.} (Figures 3-4)

Etymology. Generic epithet, Microlobiusxylon, refers to its resemblance to the extant genus Microlobius. Specific epithet, paranaensis, refers to Paraná city, the locality where this fossil was recovered.

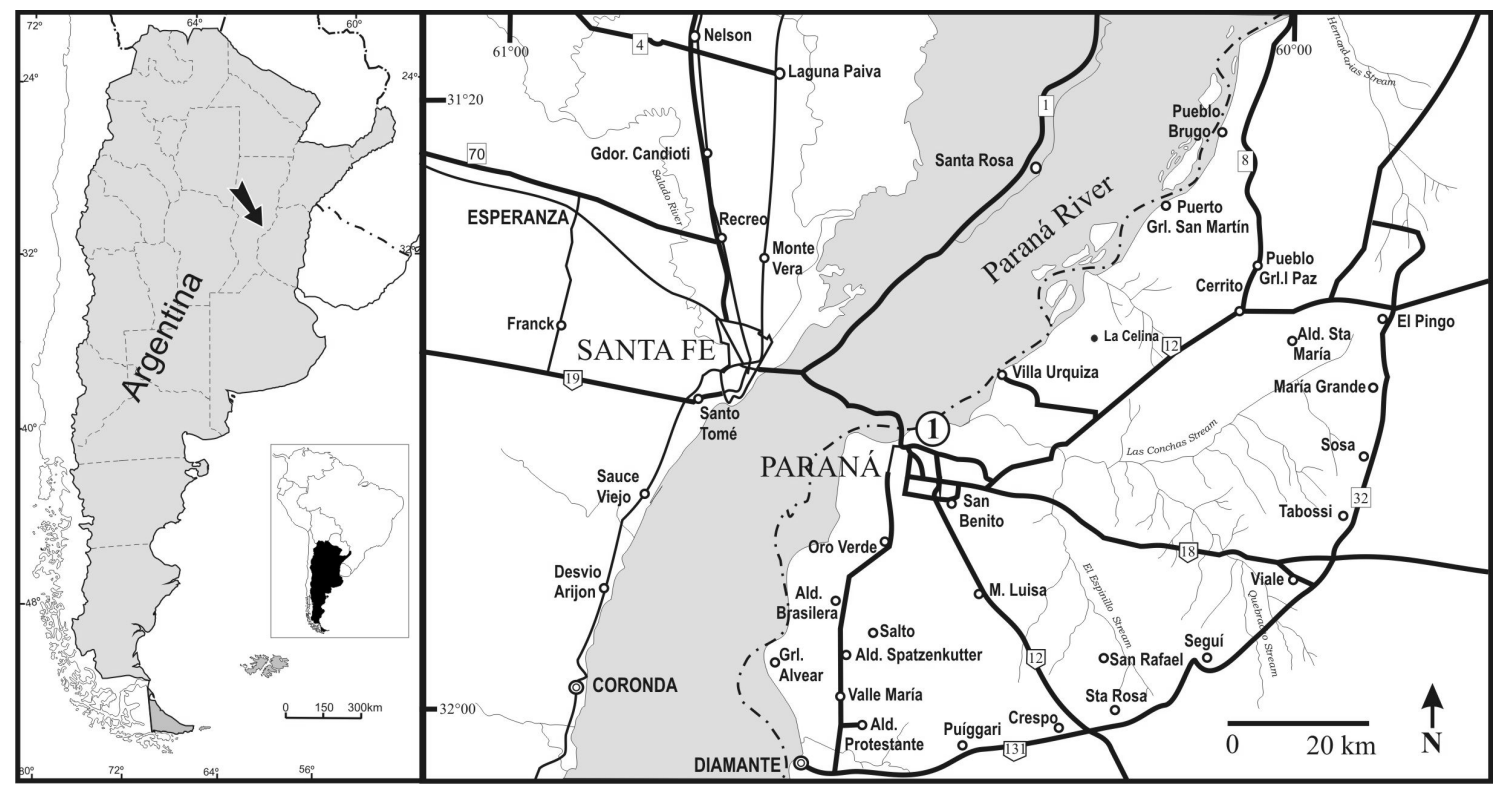

Figure 1. Location map showing the Toma Vieja fossiliferous locality (1), Entre Ríos, Argentina. 
Holotype. CIDPALBO 25, CIDPALBOmic 675.

Type locality. Toma Vieja, Paraná, Entre Ríos.

Stratigraphy. Ituzaingó Formation.

Age. Pliocene-Pleistocene.

Diagnosis. Diffuse porosity; growth rings weakly delimited; vessels mostly solitary, in radial multiples of 2-3 and rarely in clusters, narrow, $<30$ per $\mathrm{mm}^{2}$; perforation plates exclusively simple; intervessel pits minute-small, bordered, alternate, rounded and vestured; axial parenchyma very abundant, vasicentric to aliform and confluent; parenchyma strand, 4-5 cells per parenchyma strand, rays homocellular composed of procumbent cells, commonly 1-2 cells wide, numerous (6-10 rays $/ \mathrm{mm}$ ) and small; non-septate fibers oval to polygonal in outline and form the ground mass. Crystals present in chambered axial parenchyma cells.

Description. This description is based on three pieces of the same fossil wood measuring $15.5 \mathrm{~cm}, 10 \mathrm{~cm}$ and $10.8 \mathrm{~cm}$ in length and $3.5 \mathrm{~cm}, 3 \mathrm{~cm}$ and $1.5 \mathrm{~cm}$ in diameter. Pith, primary xylem, outer cortex, and secondary phloem are not preserved.
Growth rings are absent or weakly delimited. Porosity is diffuse (Figure 3A). Vessels are more or less circular, with a mean wall of $8(5-13) \mu \mathrm{m}$ thick. Vessel elements are mostly solitary $(71 \%)$; in radial multiples of $2-3$ or more $(20 \%, 6 \%$ and $1 \%$, respectively) and rarely in clusters (1\%) (Figures 3A, D, 4A-B). Vessel elements are $72(45-115) \mu \mathrm{m}$ in tangential diameter and 96 (55-175) $\mu \mathrm{m}$ in radial diameter. Vessel density is $20(17-28)$ per $\mathrm{mm}^{2}$. Vessel element length is $164(105-250)$ $\mu \mathrm{m}$. Perforation plates are exclusively simple (Figure 4C), with transverse or oblique end walls (Figure 4F). Intervessel pits minute-small, bordered, alternate, rounded and vestured (Figures 4D-E). Ground tissue fibers are circular to polygonal in outline, non-septate, with a diameter of 13 (10-18) $\mu \mathrm{m}$ and a thickness of 3 (2-5) $\mu \mathrm{m}$ (Figure 3E). Vessel-ray pitting poorly preserved, possibly bordered. The axial parenchyma is vasicentric, confluent and aliform (Figures 3A, D). Axial parenchyma strands of 4-5 cells. Crystals present in chambered axial parenchyma cells (Figure $3 \mathrm{H}$ ). The rays are uniseriate or less commonly biseriate (Figures 3B-C). Height
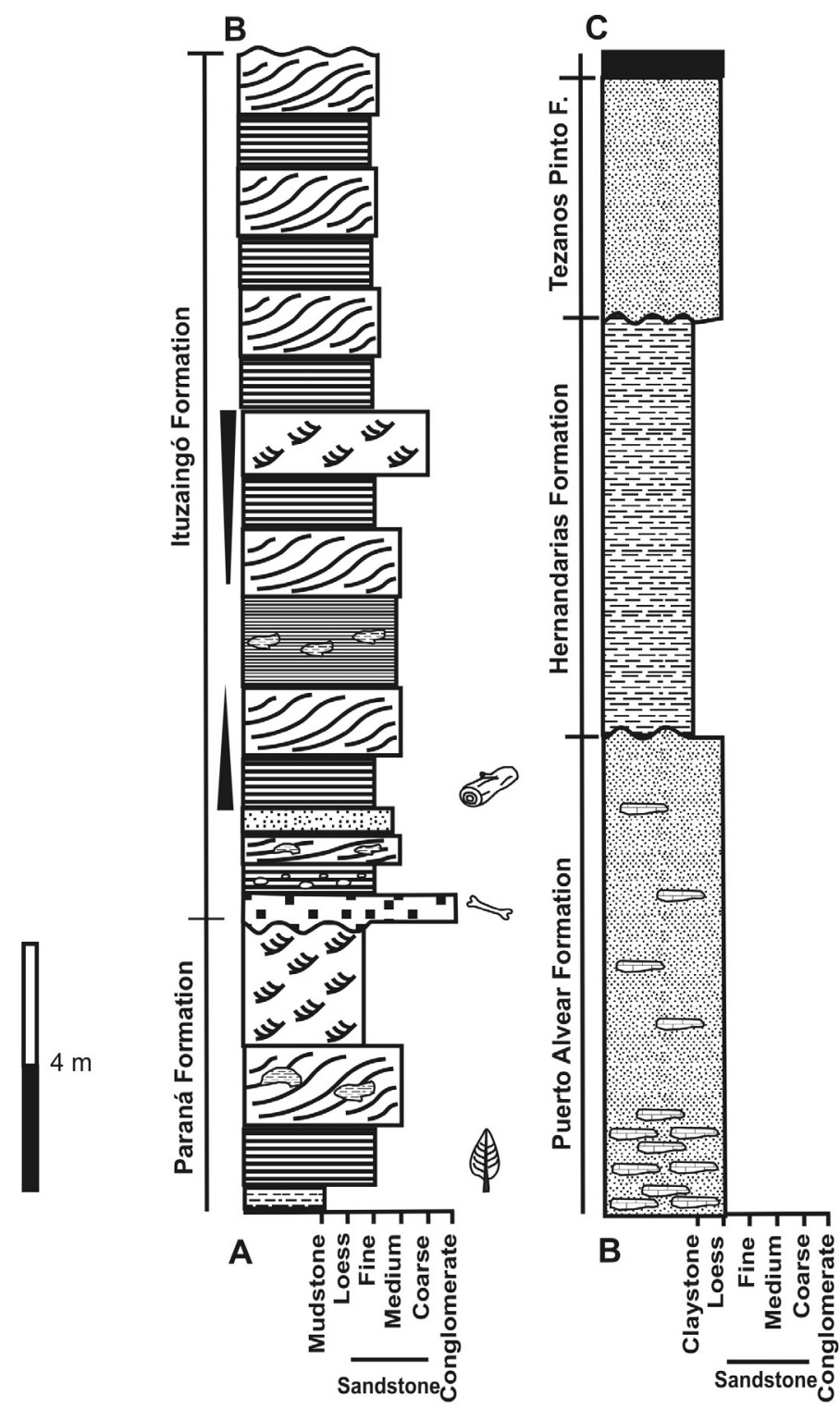

\section{Legend}

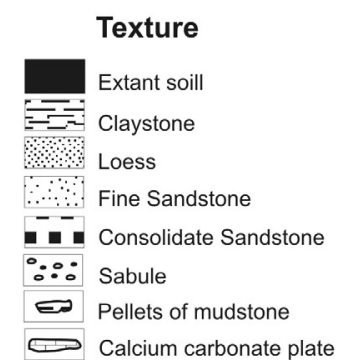

\section{Structures}

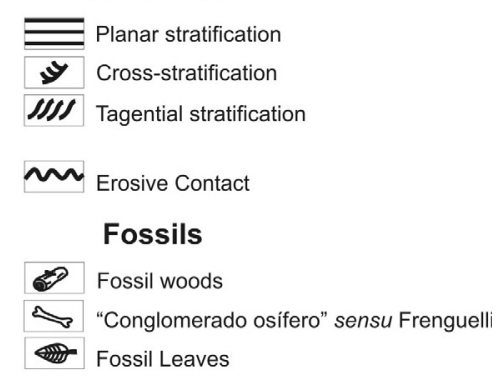

Figure 2. Schematic profile at the Toma Vieja locality, Entre Ríos, Argentina. 


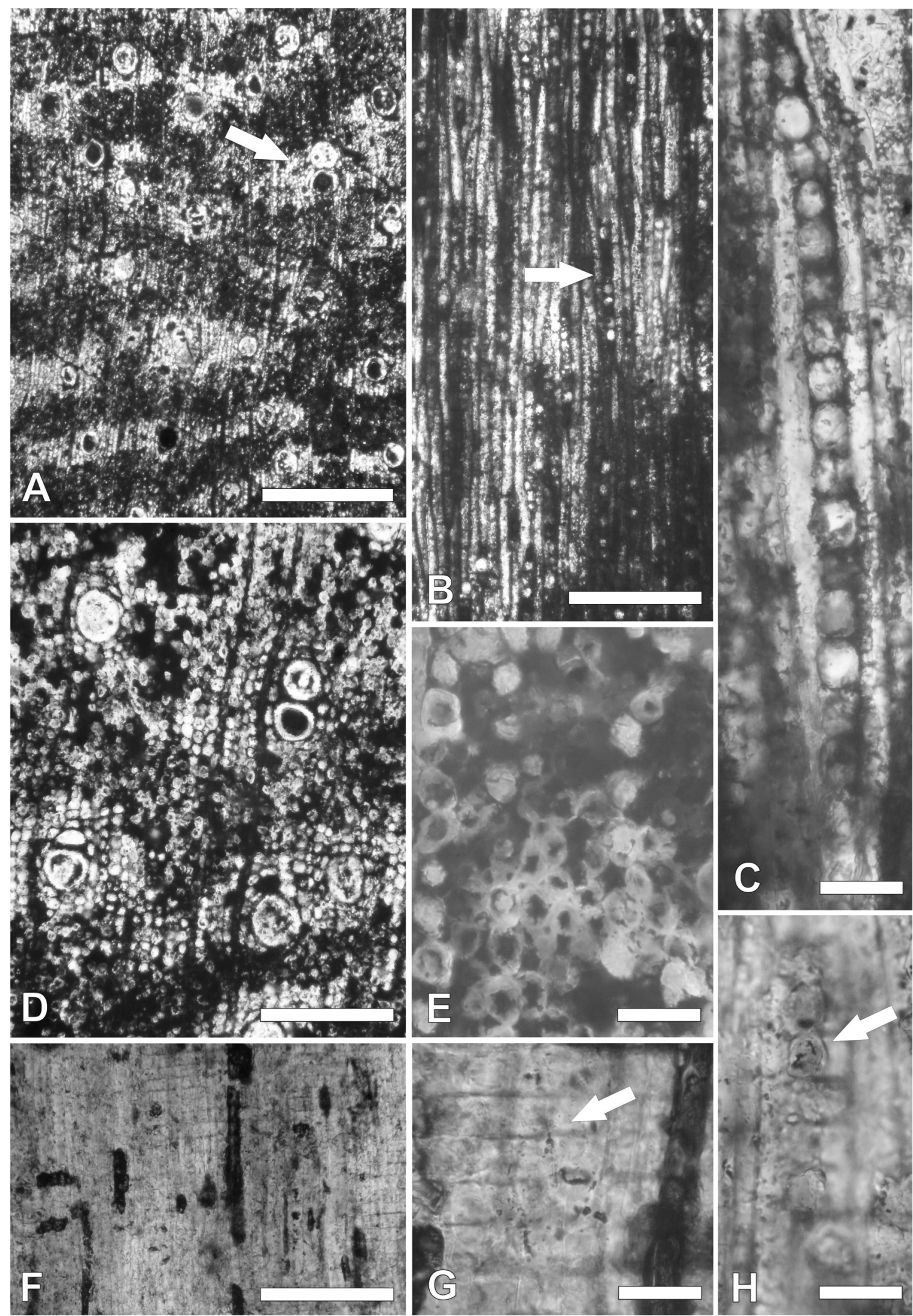

Figure 3. A-H, Microlobiusxylon paranaensis gen. et sp. nov. A, Cross section showing diffuse porous wood with randomly arranged vessels, aliform-confluent parenchyma (arrow); B, Tangential section showing predominantly uni- (arrow) and biseriate rays; C, uniseriate ray; $\mathbf{D}$, detail showing solitary vessels and short radial multiples of vessels and confluent parenchyma; $\mathbf{E}$, in cross section, detail of fibers; $\mathbf{F}$, radial section showing homocellular rays; $\mathbf{G}$, detail of procumbent ray cells (arrow); $\mathbf{H}$, crystals in chambered axial parenchyma cells (arrow). Scale bars: A $=500 \mu \mathrm{m} ; \mathrm{B}, \mathrm{D}, \mathrm{F}=200 \mu \mathrm{m} ; \mathrm{C}, \mathrm{E}, \mathrm{G}, \mathrm{H}=20 \mu \mathrm{m}$. 
of rays is $170(45-520) \mu \mathrm{m}$ and 11 (4-35) cells high. Width of rays is $13(10-20) \mu \mathrm{m}$. There are $8(6-10)$ rays per linear $\mathrm{mm}$. Rays are homogeneous type I of Kribs and homocellular composed exclusively of procumbent cells (Figures 3F-G).

Comparison with extant species. Synapomorphies that relate this fossil wood to the Fabales are the presence of vestured pits and vessel elements with simple perforation plates (Judd et al.,1999).The anatomical fossil wood characters (vessels solitary and in radial multiples; simple perforation plates; axial parenchyma abundant, confluent or banded; uniseriate rays, rarely biseriate, homocellular rays composed of procumbent cells and non-septate fibers) suggest a close affinity to the Fabaceae family (Metcalfe \& Chalk, 1950; Cozzo, 1951; Tortorelli, 1956; Baretta-Kuipers, 1981; Wheeler \& Baas, 1992; Barros \& Callado, 1997). These features also occur in the Sapindaceae. However, the fossil wood is different with that family in the diameter of vessels and in the fibers (Metcalfe \& Chalk, 1950).

The specimen was compared with extant and fossil species of the Fabaceae, particularly the Mimosoideae subfamily (Tables 1-2). The combination of characters (the presence or absence of septate fibers, the presence and extent of confluent or banded axial parenchyma, and ray width; Evans et al., 2006) in the Toma Vieja fossil wood is diagnostic for the Mimosoideae.
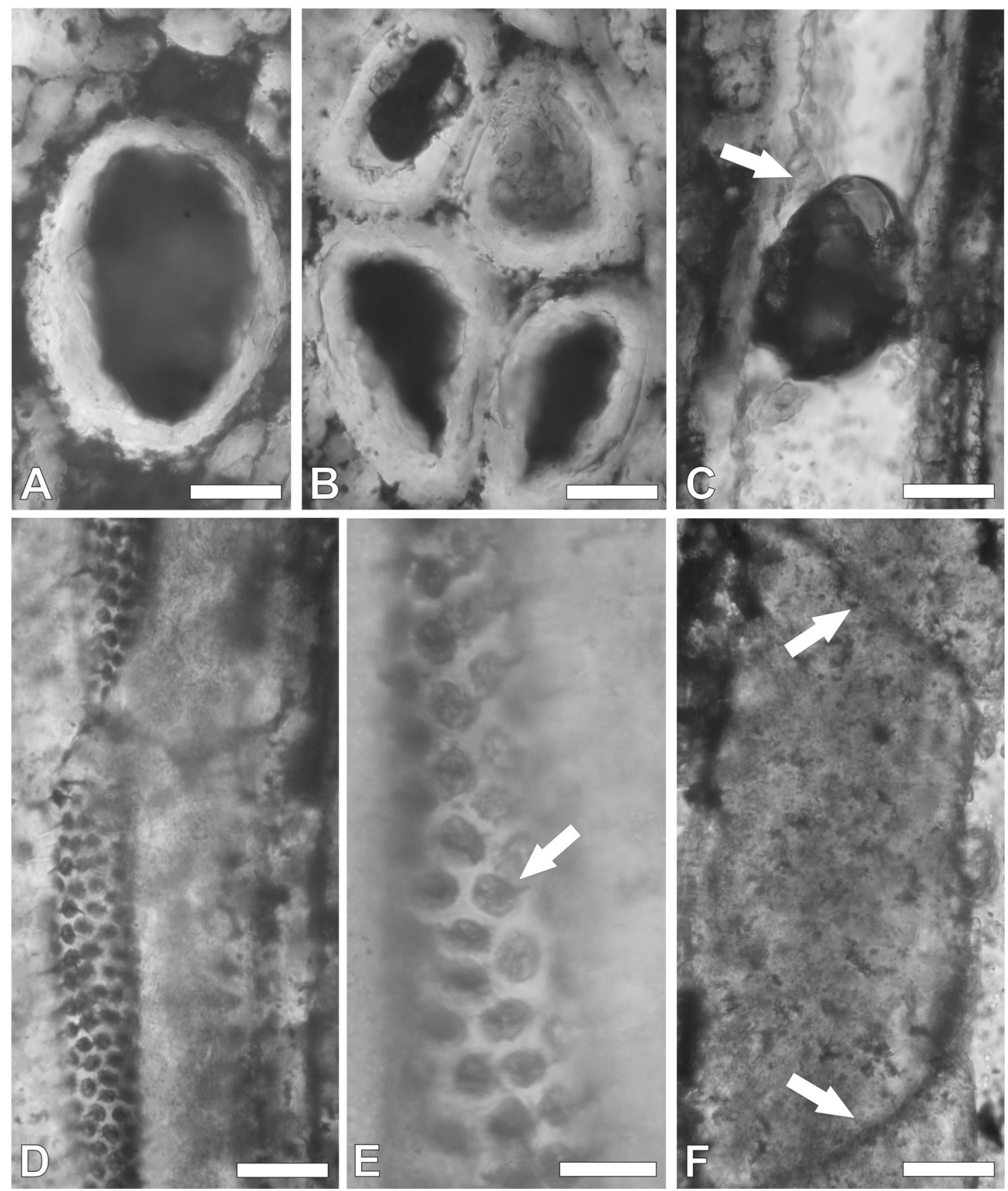

Figure 4. A-F, Microlobiusxylon paranaensis gen. et sp. nov. A, vessel solitary; B, vessel clusters in cross section; C, vessel with simple perforation plate (arrow) in tangential section; D, crowded alternate intervessel pits; E, detail of vestured intervessel pits (arrow); $\mathbf{F}$, detail of oblique end walls (arrow). Scale bars: A-D, $F=20 \mu \mathrm{m} ; E=10 \mu \mathrm{m}$. 


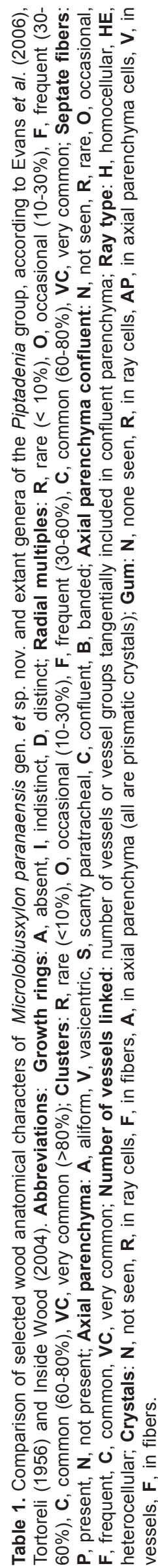

\begin{tabular}{|c|c|c|c|c|c|c|c|c|c|}
\hline ung & $\vec{x}$ & r. & 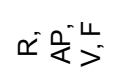 & 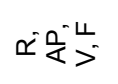 & $\vec{\square}$ & 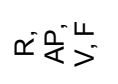 & $\check{\Upsilon} \frac{0}{<}>$ & $\overrightarrow{x^{2}}$ & $z$ \\
\hline spezsאo & $\ll$ & 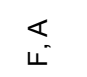 & 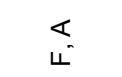 & $\underset{4}{\ll}$ & 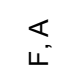 & $\ll$ & $\ll$ & 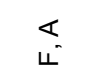 & $\ll$ \\
\hline$\partial \mathrm{d} \kappa_{\perp}$ Key & I & I & $\begin{array}{l}\stackrel{0}{1} \\
\text { 采 }\end{array}$ & 年 & I & 㺼 & I & I & $I$ \\
\hline чрр!м Кеу & $\stackrel{q}{q}$ & $\div \widehat{\widehat{N}}$ & $\stackrel{m}{\longrightarrow}$ & $\stackrel{m}{+}$ & $\stackrel{i}{1}$ & $\div$ 矛 & $\underset{\mathfrak{C}}{\sigma}$ & $\underset{\mathfrak{C}}{\sigma}$ & $\stackrel{\sim}{\check{I}}$ \\
\hline mu/s Key & $\infty$ & $\stackrel{\sim}{\infty}$ & $\frac{n}{6}$ & $\frac{\circ}{\infty}$ & $\hat{\mathfrak{g}}$ & $\frac{m}{b}$ & ஸ் & $\check{\sigma}$ & $\frac{0}{6}$ \\
\hline 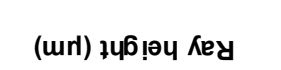 & $\stackrel{O}{N}$ & ঃ & ì & 官号 & $\stackrel{2}{\circ}$ & ํㅠㅇ & ì & ㅎํำ & 守 ำ \\
\hline 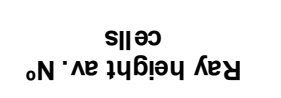 & 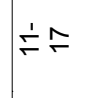 & c. & $\infty \stackrel{\circ}{\dddot{m}}$ & $\stackrel{+}{ \pm}$ & +20 & $\stackrel{y}{4}$ & ฮึ่ $\stackrel{\circ}{\circ}$ & 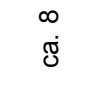 & $\stackrel{\substack{q \\
q}}{m}$ \\
\hline рәуц!! S|әssə^ jo 。N & 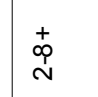 & 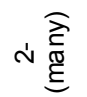 & $\stackrel{+}{+}$ & $\stackrel{+}{\stackrel{+}{\sim}}$ & $\stackrel{+}{\stackrel{+}{N}}$ & $\stackrel{+}{\stackrel{1}{N}}$ & $\stackrel{m}{\sim}$ & $\frac{N}{z}$ & 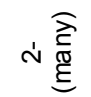 \\
\hline 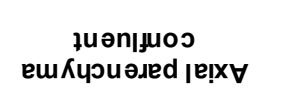 & $\sum_{\substack{1 \\
L}}^{0}$ & 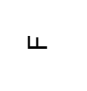 & نे & Ò & ì & $\stackrel{0}{\dot{L}}$ & 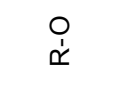 & $\begin{array}{l}\text { 은 } \\
\dot{z}\end{array}$ & 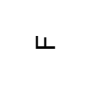 \\
\hline 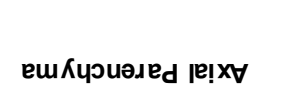 & $\$$ & $\begin{array}{l}\frac{\infty}{0} \\
\mathbb{\$} \\
\$\end{array}$ & $\begin{array}{l}0 \\
\\
\end{array}$ & $\$$ & O & $\stackrel{m}{>}$ & $\stackrel{\pi}{j}$ & ஸे & $\begin{array}{l}\frac{\infty}{0} \\
\frac{1}{>}\end{array}$ \\
\hline səxqy әңеzdəs & $z$ & $z$ & $\underset{n}{z}$ & $\underset{n}{a}$ & $z$ & $a$ & $z$ & $z$ & $z$ \\
\hline 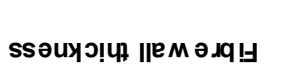 & 并 & 站弟 & 突兑 & 要㒸 & 站总 & 突尊 & 吂 & 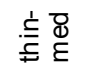 & 辛弟 \\
\hline 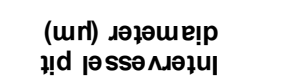 & के & ๙. & 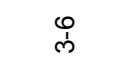 & ले & $g$ & $\stackrel{+}{\mathfrak{d}}$ & $\grave{\omega}^{\circ}$ & $\stackrel{N}{o ́}$ & c. \\
\hline גəłsn|ગ/s|əssə^ jo oN & ì & 声 & $\stackrel{\leftrightarrow}{\sim} \underset{O}{O}$ & $\hat{\sim}$ & $\stackrel{p}{\sim}$ & $\stackrel{t}{\Delta}$ & $\dot{m} \underset{\sigma}{\overparen{\sigma}}$ & $\stackrel{+}{N}$ & 岕 \\
\hline sגəłsnıכ & $\begin{array}{l}4 \\
0\end{array}$ & $\begin{array}{l}0 \\
\dot{\alpha} \\
\dot{\alpha}\end{array}$ & $\begin{array}{l}0 \\
\dot{1} \\
\dot{\alpha}\end{array}$ & 仓ेंu & $\frac{\dot{\alpha}}{z} \leftarrow$ & $\frac{u}{\alpha}$ & $\stackrel{\circ}{\propto}$ & $\stackrel{\rho}{\not{\alpha}}$ & $\simeq$ \\
\hline S|əssan jo oN & $\hat{i}$ & $\stackrel{2}{I}$ & $\stackrel{\circ}{\stackrel{1}{N}}$ & $\hat{i}$ & $\dot{\sim} \frac{\theta}{\omega n}$ & 논 & 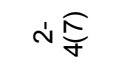 & $\hat{i}$ & $\stackrel{+}{+}$ \\
\hline sə|d!||nu ןe!pey & $\underset{\Psi}{O}$ & $\underset{\Psi}{O}$ & $\sum_{i}^{0}$ & $\sum_{0}^{0}$ & $\frac{4}{\frac{1}{\alpha}}$ & $\begin{array}{l}0 \\
\dot{\alpha} \\
\check{\alpha}\end{array}$ & $\stackrel{\mathrm{L}}{\mathrm{L}}$ & ${ }_{i}$ & 㭊 \\
\hline${ }_{z} \mathrm{mw} / \mathbf{s} \mid \partial s s \partial \Lambda$ & 这的 & 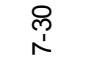 & 官莒 & ஸें & dे & m苛 & & $\dot{\forall} \underset{m}{m}$ & $\stackrel{\infty}{\sim} \stackrel{\infty}{\sim}$ \\
\hline 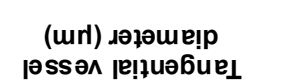 & $\infty \stackrel{\infty}{\infty}$ & 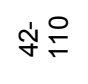 & d닫 & 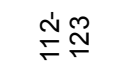 & 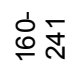 & 남욛 & 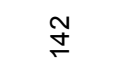 & 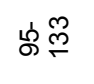 & 字官 \\
\hline sби!ı чұмодэ & 口 & $\Phi$ & $\bar{x}$ & $\stackrel{9}{<}$ & $\underline{\underline{9}}$ & $\stackrel{9}{<}$ & 口 & 모 & $\underline{\underline{P}}$ \\
\hline 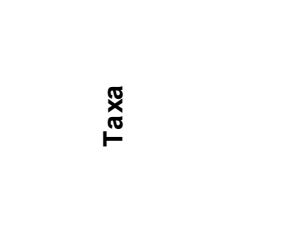 & 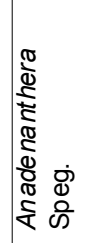 & 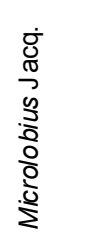 & $\begin{array}{l}\dot{3} \\
\mathbb{8} \\
0 \\
\stackrel{5}{\Sigma} \\
\sum\end{array}$ & 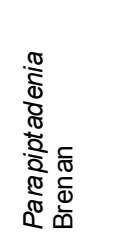 & 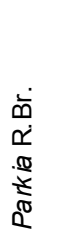 & 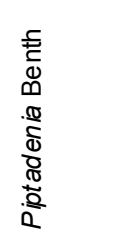 & 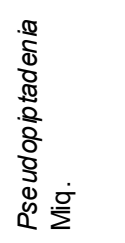 & 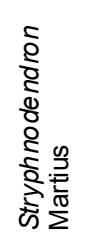 & 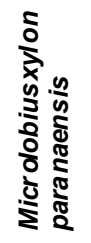 \\
\hline
\end{tabular}




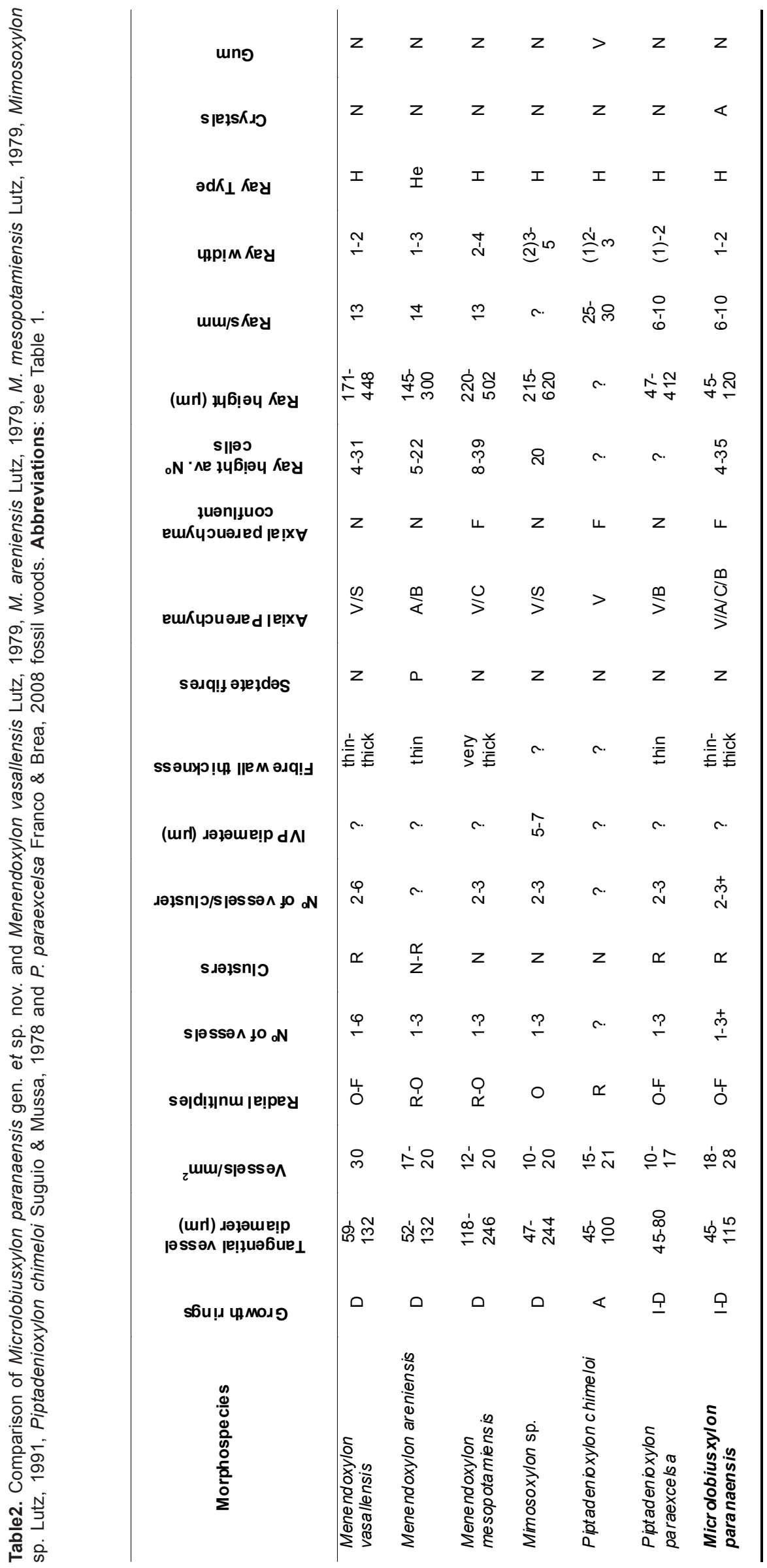


Although it would be difficult to identify a mimosoid plant to the genus level based solely on its wood anatomy, the fossil wood has diagnostic characters, which allow comparison with extant genera. The fossil wood is more related to the tribe Mimoseae, especially with the Piptadenia group. This group, with eight genera (Table 1), is the largest in the tribe Mimoseae, and their diagnostic anatomical characters are: vessels mostly small to medium-sized and high vessel density, radial multiples and clusters ranging from rare to common, which can be large or small; variable intervessel pit size ; septate and nonseptate fibers; axial parenchyma ranging from scanty to banded, and in many cases confluent parenchyma linking many vessels leading to an almost banded appearance; rays commonly 2-3 cells wide and uniseriate rays always present (Evans et al., 2006).

Microlobius C. Presl. is the most related extant genus. This species grows in Northeastern Formosa province in Argentina and is a big green foliage shrub. Usually, the following species join Microlobius in its natural habitat: Tabebuia nodosa (Griseb.) Griseb., Diplokeleba floribunda N. E. Br., Astronium balansae Engl., Aspidosperma triternatum Rojas Acosta, Peltophorum dubium (Spreng.) Taub., Crataeva tapia L., Tabebuia ipe (Mart. ex K. Schum.) Standl., Gleditsia amorphoides (Griseb.) Taub. and Caesalpinia paraguariensis (D. Parodi) Burkart (Tortorelli, 1956).

Comparisons with fossil species. The fossil record of the Leguminosae is abundant and diverse. Fossil legume fruits, leaflets, wood, flowers and pollen are known from numerous localities representing nearly all major land areas (Herendeen et al., 1992).

Fossil wood legume morphogenera referable to the Mimosoideae are: Acacioxylon Schenk, 1883, Adenantheroxylon Prakash \& Tripathi, 1968, Albizinium Prakash, 1975, Albizzioxylon Nikitin, 1935, Cathormion Gros, 1990, Dichrostachyoxylon Müller-Stoll \& Mädel, 1967, Eucacioxylon Müller-Stoll \& Mädel, 1967, Ingoxylon MüllerStoll \& Mädel, 1967, Menendoxylon Lutz, 1979, Metacacioxylon Gros, 1981, Mimosoxylon Müller-Stoll \& Mädel, 1967, Mimosaceoxylon Lakhanpal \& Prakash, 1970, Paraalbizioxylon Gros, 1992, Paracacioxylon Müller-Stoll \& Mädel, 1967, Piptadenioxylon Suguio \& Mussa, 1978, Tetrapleuroxylon Müller-Stoll \& Mädel, 1967 and Anadenantheroxylon Brea et al., 2001.

The specimen studied was compared with Menendoxylon Lutz, 1979, Mimosoxylon Lutz, 1991 and Piptadenioxylon Suguio \& Mussa, 1978 (Table 2). The most similar fossil wood is Piptadenioxylon paraexcelsa Franco \& Brea (2008). The differences between them are in: vessels per $\mathrm{mm}^{2}$, fiber wall thickness, axial parenchyma (presence of confluent parenchyma), and the frequency of uni- and biseriate rays.

The fossil wood shares anatomical features with fossil species already known. However, its morphology and anatomy present a combination of diagnostic features that allow the recognition of a new species from the PliocenePleistocene in the Parana Basin, Microlobiusxylon paranaensis.

\section{DISCUSSION}

The Fabaceae (Leguminosae) comprise the third largest family of flowering plants and include over 18,000 species distributed throughout the world in many ecological settings, from deserts of high latitudes to seasonally dry or wet tropical forests of equatorial regions (Dimitri, 1978; Lewis et al., 2005; Lavin et al., 2005). They are mostly trees, shrubs or vines, sometimes with spines (Simpson, 2006; Evans et al., 2006).

On the basis of vessel element features (exclusively simple perforation plates, vessel elements of relatively short length), ray structure (either homocellular composed of only procumbent cells, or with one or few marginal rows of square to slightly upright cells), axial parenchyma arrangement and abundance (frequently aliform-confluent), and common occurrence of storied structure, the Fabaceae have 'advanced' wood structure in the Baileyan sense (Wheeler \& Baas, 1991, 1992).

Fabales contain 9.6\% eudicot diversity (Magallón et al., 1999), of which the bulk is made up of Fabaceae. The order Fabales, including Fabaceae, Polygalaceae, Quillajaceae and Surianaceae, represents a novel hypothesis emerging from angiosperm molecular phylogenies (Bello et al., 2009). Despite good support for the order, molecular studies to date have suggested contradictory, poorly supported interfamilial relationships (Stevens, 2001; Bello et al., 2009).

The Piptadenia group is not as homogeneous as the other Mimoseae groups; there is considerable variation among individual species of the same genus. The Piptadenia group as a whole is not monophyletic (Luckow et al., 2003; Jobson \& Luckow, 2007). A moderately supported polytomy includes most piptadenioid genera (Piptadenia Benth, Pseudopiptadenia Rauscher, Microlobius C. Presl, Parapiptadenia Brenan, Mimosa L. and Stryphnodendron Mart.); this group is more closely related to the Ingeae/Acacia s. 1. (including the phyllodinous Australian acacias) clade than it is to Anadenanthera Speg. and Piptadenia viridiflora (Kunth) Benth.

The current fossil record of the Fabaceae suggests that extensive diversification took place by the Middle Eocene and that they differentiated into three subfamilies: the Caesalpinioideae, Mimosoideae and Faboideae (Papilionoideae) (Herendeen, 1992; Wheeler \& Baas, 1992).

The Fabaceae are known or presumed to have reached Eurasia by the Early Paleocene (Raven \& Axelrod, 1974) and probably spread from South to North America in Eocene time or subsequently (Raven \& Axelrod, 1974; Herendeen, 1992). The potential for migration from South America through the Caribbean during the early Tertiary was probably greater than today (Herendeen, 1992). The age of the crown group Fabales was estimated as (90-) 87 (-84) or (75-) 72 (-69) My, with the stem group age being (109-) 104 (-99) and (92-) 89 (-86) My; Bayesian relaxed clock estimates were slightly older, i.e., 100 or 112 My, respectively (Stevens, 2001).

In the Late Cenozoic, there is an increase in the number of woods with structural features that are now most common in 
markedly seasonal climates. In the Pliocene, all woods are structurally equivalent to extant wood (Wheeler \& Baas, 1992).

Piptadenia and Microlobius are related genera, and possibly the first is the ancestral one. However, they show differences that allow them to be separated one from the other (Sousa \& Andrade, 1992). Microlobius is a genus with only one species, Microlobius foetidus (Jacq.) M. Sousa \& G. Andrade, and with two subspecies: Microlobius foetidus foetidus (Jacq.) M. Sousa \& G. Andrade and Microlobius foetidus paraguensis (Benth.) M. Sousa \& G. Andrade, with a disjunct distribution (Sousa \& Andrade, 1992).

Microlobius foetidus is an endemic species of the Misiones nucleus, that is, the Paraguay-Paraná system (Prado \& Gibbs, 1993). It is native to southern South America: Brazil, Bolivia (Santa Cruz), Argentina (Chaco, Formosa) and Paraguay (Alto Paraguay, Central, Concepción, Presidente Hayes) (Zuloaga \& Morrone, 1999; USDA, 2009).

The present-day distribution of this species is considered to comprise fragmentary remnants of the once extensive forest that probably characterized the dry climatic maxima of the Pleistocene (Prado, 2000). The extant fragments of this seasonal woodland vegetation have their main nucleus in the Caatingas, Misiones, and Piedmont areas (Prado \& Gibbs, 1993).

The tropical seasonal forest region comprises at least three provinces: the Caatingas s. $l$, the Subandean Piedmont Forests and the Paranense. The Pleistocenic Arc must have been more extensive in the geological past to areas that currently cannot be safely included as part of the tropical seasonal forest region (Prado, 2000). Seasonally dry tropical forests (SDTFs) sensu Prado (2000) have woody floras dominated by the Leguminosae and Bignoniaceaee families (Pennington et al., 2000).

This assumption is supported by the previous studies from the Cenozoic Paraná Basin (Anzótegui \& Lutz, 1987; Aceñolaza \& Aceñolaza, 1996; Brea \& Zucol, 2007; Anzótegui \& Aceñolaza, 2008; Franco, 2008a,b, 2009; Franco \& Brea, 2009).

As plants are excellent tools for reconstructing paleoclimate and paleoenvironment, especially through comparison with the modern flora, the study of Fabaceae fossil wood from Ituzaingó Formation can shed new light on past floral composition and past environment and climate of the Cenozoic Paraná Basin.

\section{FINAL CONSIDERATIONS}

A new species of the Mimosoideae (Fabaceae), Microlobiusxylon paranaensis, is described from the Pliocene-Pleistocene Ituzaingó Formation from Toma Vieja fossil locality, Entre Ríos, Argentina. This fossil provides new evidence of Mimosoideae distribution in the past and is similar to the extant genera of the Piptadenia group, especially Microlobius.

Microlobiusxylon paranaensis might have been an important component of the seasonally dry tropical forests
(SDTFs) sensu Prado (2000). The presence of this fossil record from Ituzaingó Formation at the Toma Vieja fossil locality and the studies above discussed from the Cenozoic Paraná Basin support the idea that SDTFs were more widespread in the past.

The presence of Microlobiusxylon paranaensis would indicate a temperate-warm climate during the PliocenePleistocene.

\section{ACKNOWLEDGMENTS}

We are grateful to two anonymous reviewers for their constructive comments and suggested modifications, which significantly helped in improving the paper. This research was financially supported in part by PICT 2008-0176 (Agencia Nacional de Promoción Científica y Técnológica).

\section{REFERENCES}

Aceñolaza, F.G \& Aceñolaza, G.F. 1996. Improntas foliares de una Lauraceae en la Formación Paraná (Mioceno superior), en Villa Urquiza, Entre Ríos. Ameghiniana, 33:155-159.

Aceñolaza, F.G. \& Sayago, J.M. 1980. Análisis preliminar sobre la estratigrafía, morfodinámica y morfogénesis de la región de Villa Urquiza, provincia de Entre Ríos. Acta Geologica Lilloana, 15:139-154.

Anis, K.B.; Georgieff, S.M.; Rizo, G.E. \& Orfeo, O. 2005. Arquitectura de la Formación Ituzaingó (Plioceno), una comparación con los depósitos del río Paraná, Argentina. In: CONGRESO GEOLÓGICO ARGENTINO, 16, 2005. Actas, La Plata, AGA, 3:147-154.

Anzótegui, L.M. 1975. Esporomorfos del Terciario superior de la provincia de Corrientes, Argentina. In: CONGRESO ARGENTINO DE PALEONTOLOGÍA Y BIOESTRATIGRAFÍA, 1, 1975. Actas, Tucumán, UNT/APA, 2:318-329.

Anzótegui, L.M. 1980. Cutículas del Terciario superior de la provincia de Corrientes, República Argentina. In: CONGRESO ARGENTINO DE PALEONTOLOGÍA Y BIOESTRATIGRAFÍA Y I CONGRESO LATINOAMERICANO DE PALEONTOLOGÍA, 2, 1980. Actas, Buenos Aires, APA, 3:141-167.

Anzótegui, L.M. \& Aceñolaza, P.G. 2008. Macrofloristic assemblage of the Paraná Formation (Middle-Upper Miocene) in Entre Ríos (Argentina). Neues Jahrbuch für Geologie und Paläontology, 248:159-170.

Anzótegui, L.M. \& Acevedo, T.L. 1995. Revisión de Ilexpollenits Thiergart y una nueva especie del Plioceno superior (Formación Ituzaingó) de Corrientes, Argentina. In: CONGRESO ARGENTINO DE PALEONTOLOGÍA Y BIOESTRATIGRAFÍA, 6, 1995. Actas, Trelew, MEF, p. 15-21.

Anzótegui, L.M. \& Garralla, S.S. 2004. Palinología del Cuaternario en el Iberá, provincia de Corrientes. In: F.G. Aceñolaza (ed.) Temas de la biodiversidad del litoral fluvial argentino. INSUGEO, Miscelánea, 12:91-102.

Anzótegui, L.M. \& Lutz, A.I. 1987. Paleocomunidades vegetales del Terciario superior (Formación Ituzaingó) de la mesopotamia argentina. Revista de la Asociación de Ciencias Naturales del Litoral, 18:131-144.

APG II. 2003. An update of the Angiosperm Phylogeny Group classification for the orders and families of flowering plants: 
APG II. Botanical Journal of the Linnean Society, 141:399436.

Baretta-Kuipers, T. 1981. Wood anatomy of Leguminosae: its relevance to taxonomy. In: R.M. Polhill \& P.H. Raven (eds.) Advances in legume systematic, Part 2, Royal Botanical Gardens, p. 677-705.

Barros, C.F. \& Callado, C.H. 1997. Madeiras da Mata Atlântica. Anatomia do lenho de espécies ocorrentes nos remanescentes florestais do Estado do Rio de Janeiro- Brasil. Rio de Janeiro, Jardim Botânico do Rio de Janeiro, v. 1, 86 p.

Bello, M.A.; Bruneau, A.; Forest, F. \& Hawkins, J.A. 2009. Elusive relationships within order Fabales: phylogenetic analyses using matK and rbcL sequence data. Systematic Botany, 34:102-114.

Brea, M. \& Zucol, A. F. 2007. Guadua zuloagae sp. nov., the first petrified bamboo culm record from the Ituzaingó Formation (Pliocene), Paraná Basin, Argentina. Annals of Botany, 100:711724.

Brea, M.; Aceñolaza, P.G. \& Zucol, A.F. 2001. Estudio paleoxilológico en la Formación Paraná, Entre Ríos, Argentina. Asociación Paleontológica Argentina: In: SIMPOSIO ARGENTINO DE PALEOBOTÁNICA Y PALINOLOGÍA, 11, 2001. Publicación especial, Buenos Aires, ALPP, 8:7-17.

Caccavari, M.A. \& Anzótegui, L.M. 1987. Polen de Mimosoideae (Leguminosae) de la Formación Ituzaingó, Plioceno superior de Corrientes, Argentina. In: CONGRESO LATINOAMERICANO DE PALEONTOLOGÍA, 4, 1987. Actas, Santa Cruz de la Sierra, ABP/YPFB, 1:443-458.

Carlquist, S. 2001. Comparative wood anatomy. Systematic, ecological, and evolutionary aspects of dicotyledon wood. Berlin, Springer, $448 \mathrm{p}$.

Cozzo, D. 1951. Anatomía del leño secundario de las leguminosas mimosoideas y cesalpinoideas argentinas silvestres y cultivadas. INICN/MABR, Ciencias Botánicas, 2:63-146.

D'Orbigny, A. 1842. Voyage dans l'Amérique Méridionale le Bresil,la République Orientale de l'Uruguay, la République Argentine, la Patagonie, la République du Chili, la République de Bolivia, la République du Pérou, Execute Pédant les Années 1826, 1827, 1828, 1829, 1830, 1831, 1832 et 1833. Geologie, Paris, v. 3, $290 \mathrm{p}$.

De Alba, E. 1953. Geología del Alto Paraná en relación con los trabajos de derrocamiento entre Ituzaingó y Posadas. Revista de la Asociación Geológica Argentina, 8:129-161.

Dimitri, M.J. 1978. Enciclopedia argentina de agricultura y jardinería. Buenos Aires, ACME, v. 1,161 p.

Evans, J.A.; Gasson, P.E. \& Lewis, G.P. 2006. Wood anatomy of the Mimosoideae (Leguminosae). IAWA Journal, 5:1-117.

Franco, M.J. 2008a. Nuevos registros de maderas fósiles de Anacardiaceae en la Formación Ituzaingó (Plioceno), Toma Vieja, Paraná, Entre Ríos, Argentina. Ameghiniana, 45(4):28R (Supplement).

Franco, M. J. 2008b. Leño fósil de Mimosoideae en la Formación Ituzaingó (Plioceno), Toma Vieja, Paraná, Entre Ríos, Argentina. Ameghiniana 45(4):28R (Supplement).

Franco, M.J. 2009. Leños fósiles de Anacardiaceae en la Formación Ituzaingó (Plioceno), Toma Vieja, Paraná, Entre Ríos, Argentina. Ameghiniana, 46:587-604.

Franco, M.J. \& Brea, M. 2008. Leños fósiles de la Formación Paraná (Mioceno Medio), Toma Vieja, Paraná, Entre Ríos, Argentina: registro de bosques estacionales mixtos. Ameghiniana, 45:699-718.

Franco, M.J. \& Brea, M. 2009. Primer registro de leños fósiles de
Moraceae y Rutaceae de la Formación Ituzaingó (PliocenoPleistoceno), Toma Vieja, Paraná, Argentina. In: CONGRESO ARGENTINO DE CUATERNARIO Y GEOMORFOLOGÍA, 4/ CONGRESSO DA ASSOCIAÇÃO BRASILEIRA DE ESTUDOS DO QUATERNARIO, 12/ REUNIÓN SOBRE EL CUATERNARIO DE AMÉRICA DEL SUR, 2, 2009. Actas, La Plata, AACG/ABEQUA, p. 639-647.

Garralla, S. 1987. Palinomorfos (Fungi) de la Formación Ituzaingó (Plioceno Superior) de la provincia de Corrientes, Argentina. Facena, 7:87-109.

Gregory, M. 1994. Bibliography of systematic wood anatomy of dicotyledons. IAWA Journal, 1:1-265.

Gros, J.P. 1981. Nouveaux bois du Cénozoique d'Autriche et d'Ethiopie. Université Claude Bernard Lyon I, Thèse 3 ème Cycle, 143 p.

Gros, J.P. 1990. Etudes xylotomiques et systematiques de bois fossil cenozoiques de la basse vallee de l'Omo, Ethiopie. Leurs apports a la connaissance des Bignoniaceae, Irvingiaceae, Mimosaceae, Rubiaceae fossiles et a la reconstitution des flores et vegetations ligneuses passees. Université Claude Bernard Lyon I, Thesis Doctorat ès Science, $560 \mathrm{p}$.

Gros, J.P. 1992. A sinopsis of the fossil record of mimosoid legume Wood. In: P.S. Herendeen \& D.L. Dilcher (eds.) Advances in legume systematics, part 4: the fossil record, Royal Botanic Gardens, p. 69-83.

Herbst, R. 1971. Esquema estratigráfico de la provincia de Corrientes, República Argentina. Revista de la Asociación Geológica Argentina, 26:221-243.

Herbst, R. 2000. La Formación Ituzaingó (Plioceno). Estratigrafía y distribución. In: F.G. Aceñolaza \& R. Herbst (eds.) El Neógeno en la Argentina. INSUGEO, Serie de Correlación Geológica, 14:181-243.

Herbst, R. \& Santa Cruz, J.N. 1985. Mapa litoestratigráfico de la provincia de Corrientes. D'Orbignyana, 2:1-69.

Herbst, R.; Santa Cruz, J.N. \& Zabert, L.L. 1976. Avances en el conocimiento de la estratigrafía de la Mesopotamia Argentina, con especial referencia a la provincia de Corrientes. Revista de la Asociación de Ciencias Naturales del Litoral, 7:101-121.

Herendeen, P.S. 1992. The fossil history of the Leguminosae from the Eocene of southeastern North America. In: P.S. Herendeen \& D.L. Dilcher (eds.) Advances in legume systematics, part 4: the fossil record, Royal Botanic Gardens, p. 85-160.

Herendeen, P.S., Crepet, W. L \& Dilcher. 1992. The fossil history of the Leguminosae: phylogenetic and biogeographic implication. In: P.S. Herendeen \& D.L. Dilcher (eds.) Advances in legume systematics, part 4: The fossil record, Royal Botanic Gardens, p. 303-316.

IAWA Committe. 1989. IAWA list of microscopic feature for hardwood identification. IAWA Bulletin, 10: 219-332.

InsideWood. 2004-onwards. Available at http:// insidewood.lib.ncsu.edu/search; accessed on 06/10/2009.

Iriondo, M.H. 1979. Origen y evolución del río Paraná. In: JORNADAS DEL PARANÁ MEDIO, 2, 1979. Actas, Santa Fe, Universidad Nacional del Litoral, 11:33-37.

Iriondo, M.H. 1980. El Cuaternario de Entre Ríos. Revista de la Asociación de Ciencias Naturales del Litoral, 11:125-141.

Iriondo, M.H. 1996. Estratigrafía del Cuaternario de la Cuenca del Río Uruguay. In: CONGRESO GEOLÓGICO ARGENTINO, 13/ CONGRESO DE EXPLORACIÓN DE HIDROCARBUROS, 3, 1996. Actas, Buenos Aires, AGA/IAPG, 4:15-25. 
Iriondo, M.H. \& Kröhling, D. 2009. From Buenos Aires to Santa Fe: Darwin's observations and modern knowledge. Revista de la Asociación Geológica Argentina, 64:109-123.

Iriondo, M.H.; Kröhling, D. \& Orfeo, O.1998. Excursion guide $\mathrm{N}^{\circ}$ 4, Loess in Argentina: temperate and tropical. Tropical Realm (provinces of Corrientes and Misiones). In: INTERNATIONAL JOINT FIELD MEETING, 1, 1998. Actas, Paraná, INQUA, p. $1-27$.

Iriondo, M.H. \& Rodríguez, E.D. 1973. Algunas características sedimentológicas de la Formación Ituzaingó entre La Paz y Pueblo Brugo (Entre Ríos). In: CONGRESO GEOLÓGICO ARGENTINO, 5, 1973. Actas, Villa Carlos Paz, AGA, 1:317331.

Jalfin, G.A. 1988. Formación Ituzaingó (Plio-Pleistoceno) en Empedrado, provincia de Corrientes: un paleorío arenoso entrelazado tipo Platte. In: REUNIÓN ARGENTINA DE SEDIMENTOLOGÍA, 2, 1988. Actas, Buenos Aires, AAS, p. 130-134.

Jobson, R.W. \& Luckow, M. 2007. Phylogenetic study of the genus Piptadenia (Mimosoideae: Leguminosae) using plastic trnL-F and trnK/matK sequence data. Systematic Botany, 32(3):569575.

Judd, W.; Campbell, C.; Kellogg, E. \& Stevens, P. 1999. Plant systematics. Sunderland, Sinauer Associates Inc., 464 p.

Lakhanpal, R.N. \& Prakash, U. 1970. Cenozoic plants from Congo. 1- Fossil woods from de Miocene of Lake Albert. Annals of the Royal Museam of Central Africa, Sciences Géologique, 64:1-20.

Lavin, M.; Herendeen, P.S. \& Wojciechowski, M.F. 2005. Evolutionary rates analysis of Leguminosae implicates a rapid diversification of lineages during Tertiary. Systematic Biology, 54:530-549.

Lewis, G.; Schrire, B.; Mackinder, B. \& Lock, M. 2005. Legumes of the World. Kew, Royal Botanic Gardens. 577 p.

Luckow, M.; Miller, J.T.; Murphy, D.J \& Livshultz, T. 2003. A phylogenetic analisys of the Mimosoideae (Leguminoseae) based on chloroplast DNA sequence data. In: B.B. Klitgaard \& Bruneau (eds.) Advances in legume systematics, part 10: Higher Level Systematic, Royal Botanic Gardens, p. 197-220.

Lutz, A.I. 1979. Maderas de Angiospermas (Anacardiaceae y Leguminosae) del Plioceno de la Provincia de Entre Rios, Argentina. Facena, 3:39-63.

Lutz, A.I. 1991. Descripción anatómica de Mimosoxylon sp. del Plioceno (Formación Ituzaingó) de la provincia de Corrientes, Argentina. Revista de la Asociación de Ciencias Naturales del Litoral, 22:3-10.

Lutz, A.I. 1993. Dos basidiomicetes (Polyporaceae) xilófilos del Plioceno en Entre Ríos, Argentina. Ameghiniana, 30:419-422.

Lutz, A.I.; Anzótegui, L.M.; Arce, F.E.; Zurita, A.E. \& Miñon Boilini, A.R. 2007. Una nueva localidad plantífera en el Plioceno de la provincia de Corrientes, Argentina. Ameghiniana, 44(4):81R (Supplement).

Magallón, S.; Crane, P.R. \& Herendeen, P.S. 1999. Phylogenetic patterns, diversity and diversification of eudicots. Annals of the Missouri Botanical Garden, 86:297-372.

Metcalfe, C.R. \& Chalk, L. 1950. Anatomy of the Dicotyledons. Oxford, Claredon Press, 724 p.

Müller-Stoll, W.R. \& Mädel, E. 1967. Die fossilen LeguminosenHölzer. Eine Revision der mit Leguminosen verglichenen fossilen Hölzer und Beschreibugen älterer und neuer Arten. Palaeontographica B, 119:95-174.

Nikitin, A.A. 1935. A new wood from the Upper Pliocene of eastern
Georgia. Trudy Neftyanogo Geologo Azvedochnogo Instituta, series $B, \mathbf{5 1}: 51-52$.

Pennington, R.T.; Prado, D.E. \& Pendry, C.A. 2000. Neotropical seasonally dry forest and Quatenary vegetation changes. Journal of Biogeography, 27:261-273.

Prado, D.E. 2000. Seasonally dry forest of tropical South America: from forgotten ecosystems to a new phytogeographic unit. Edinburgh Journal of Botany, 57:437-461.

Prado, D.E. \& Gibbs, P.E., 1993. Patterns of species distributions in the dry seasonal forests of South America. Annals of Missouri Botanical Garden, 80:902-927.

Prakash, U. 1975. Fossil woods from the Lower Siwalik beds of Himachal Pradesh, India. Palaeobotanist, 22:192-210.

Prakash, U. \& Tripathi, P.P. 1968. Fossil woods of Adenanthera and Swintonia from the Tertiary of Assam. Current Science, 37:115-116.

Raven, P.H. \& Axelrod, D.I. 1974. Angiosperm biogeography and past continental movements. Annals of the Missouri Botanical Garden, 61:539-673.

Richter, H.G. \& Dallwitz, M.J. 2000 onwards. Commercial timbers: descriptions, illustrations, identification and information retrieval. Available at http://www: http//biodiversity.uno.edu/ delta/; accessed on 10/18/2009.

Schenk, A. 1883. Fossile Hölzer in K. Zittel -Beiträge zur Geologie und Paläontologie der Libyschen Wüste. II Abt. 1. Palaeontographica, 30:1-19.

Simpson, M.G. 2006. Plant systematics. London, Elsevier Academic Press, $590 \mathrm{p}$.

Sousa, S.M. \& Andrade, N.G. 1992. Identidad de Microlobius y Goldmania (Leguminosae: Mimosoideae: Mimoseae) y nuevas combinaciones. Anales del Instituto de Biología, UNAM, Serie Botánica, 63:101-107.

Stevens, P. F. 2001-onwards. Angiosperm Phylogeny Website. Version 9, June 2008. Available at http://www.mobot.org/ MOBOT/research/APweb/; accessed on 06/09/2009.

Suguio, K. \& Mussa, D. 1978. Madeiras fósseis dos aluviões antigos do Rio Tietê, São Paulo. Boletim IG USP, 9:25-45.

Tortorelli, L.A. 1956. Maderas y bosques argentinos. Buenos Aires, Ed. ACME, $910 \mathrm{p}$.

USDA - National Genetic Resources Program. 2009. Germplasm Resources Information Network - (GRIN), National Germplasm Resources Laboratory, Beltsville, Maryland. Available at http:/ /www.ars-grin.gov/cgi-bin/npgs/html/taxon.pl?594; accessed on 04/20/2009.

Wagemann, W. 1948. Maderas chilenas. Contribución a su anatomía e identificación. Lilloa, 16:263-375.

Wheeler, E.A. \& Baas, P. 1991. A survey of the fossil record for dicotyledonouns wood and its significance for evolutionary and ecological wood anatomy. IAWA Bulletin, 12:275-332.

Wheeler, E. \& Baas, P. 1992. Fossil wood of the Leguminosae: a case sutdy in xylem evolution and ecological anatomy. In: P.S. Herendeen \& D.L. Dilcher (eds.) Advances in legume systematics, part 4: the fossil record, Royal Botanic Gardens, p. 207-223.

Wheeler, E.A.; Rodgers, S.L. \& Baas, P. 2007. Variations in dicot wood anatomy. A global analysis. IAWA Journal, 28:229-258.

Wheeler, E.A.; Simpson, T.D.; Rodgers, S.L.; Gasson, P.E.; Brown, K.R.; Bartlett, J.R. \& Baas, P. 2004. InsideWood: a new internetaccessible wood anatomy database. In: BOTANICAL SOCIETY OF AMERICA ANNUAL MEETING, Botany 2004. Abstract, Snowbird, BSA, p. 302. 
Zucol, A.F.; Brea, M.; Lutz, A.I. \& Anzótegui, L.M. 2004. Aportes al conocimiento de la paleodiversidad del Cenezoico superior del litoral argentino: estudios paleoflorísticos. In: F.G. Aceñolaza (ed.) Temas de la biodiversidad del litoral fluvial Argentino, INSUGEO, Miscelánea 12:91-102.
Zuloaga, F.O. \& Morrone, O. 1999. Catálogo de las plantas vasculares de la República Argentina II. Saint Louis, Missouri Botanical Garden, 1269 p. (Monographs in Systematic Botany 74).

Received in September, 2009; accepted in June, 2010. 